\title{
Empowering Farmers in Improving Farmer Business Performance: Study at the "Mugi Rahayu" Farmer Group in Ponorogo Regency Indonesia
}

\author{
Ellyn Sugeng Desyanty \\ Department of Non-formal Education \\ State University of Malang, Indonesia \\ ellynsugeng@fip.um.ac.id
}

\author{
Zulkarnain \\ Department of Non-formal Education \\ State University of Malang, Indonesia \\ zulkarnain.fip@um.ac.id
}

\author{
Nurhadi \\ Department of Non-formal Education \\ State University of Malang, Indonesia \\ nurhadi.fip@um.ac.id
}

\begin{abstract}
Empowerment of farmers is needed with the aim of farmers having expertise that can help their activities towards independent farming and able to compete, able to establish cooperation with fellow farmers and with institutions of agricultural science or technology. This research is a study that uses a qualitative approach with a qualitative approach with phenomenological design to reveal the description of the efforts made by field agricultural extension officers in empowering farmers to improve the performance of farming in the "Mugi Rahayu" Farmer Group in Tegalsari Village, Jetis District, Ponorogo Regency. Empowerment of farmers in the farmer group "Mugi Rahayu" was carried out through extension activities carried out by field agricultural extension workers. Extension activities are carried out routinely to deliver material that is felt to be the learning needs of farmers in recognizing problems and finding solutions to existing problems in accordance with the characteristics and potential of the land owned. Empowerment of farmers through extension activities carried out through a series of processes consisting of planning, implementation and evaluation. The series of processes are carried out jointly between farmer groups, extension agents, and farmers as learning targets. Improving the performance of farms is not only seen from the addition of the amount of farm income every harvest period, the empowerment of farmers can also be seen from the ability of farmers to recognize problems and seek problem solving independently.
\end{abstract}

Keywords: empowering farmers, improving farmer, business performance

\section{INTRODUCTION}

Most of the Indonesian population has a livelihood in agriculture so that Indonesia is known as an agricultural country that is proven by natural conditions that are very supportive with a vast expanse of land and a tropical climate that supports the development of agriculture in Indonesia. Based on BPS data (Central Bureau of Statistics) in 2014, the number of people working in the agricultural sector amounted to around 38.97 million people, this number reached $44 \%$ of the total workforce in Indonesia. The majority of Indonesians have used natural resources to support their living needs and most of them as BPS data of the Indonesian population depend on the agricultural sector. Lincoln et al (2011) explained that in agricultural countries the agricultural sector has a role and function in economic development, among others: (1) producers of food and raw materials for the agricultural, non-agricultural, and industrial developers; (2) the agricultural sector is the biggest absorber of labor; (3) the agricultural sector can create demand for non-agricultural products which is a prerequisite for the secondary and tertiary sectors; and (4) the agricultural sector can become a foreign exchange earner from the export of commercial agricultural products.

Empowerment of farmers is needed with the aim of farmers having expertise that can help their activities towards independent farming and able to compete, able to establish cooperation with fellow farmers and with institutions of agricultural science or technology. The implementation of agricultural agriculture extension aims to enable farmers and do it independently, namely from farmers, by farmers, and for farmers (Iqbal, 2008). Not all farmers have sufficient knowledge and insight to be able to understand the problems that arise in the activities they do, analyze problems and choose problem solving in accordance with the conditions faced to achieve farmers' goals that will affect the ability of farmers to do their daily work.

Field agriculture extension workers have a role as learners for farmers, agricultural extension is non-formal education for farmers which includes activities that will increase the knowledge and skills of extension workers to farmers and their families through the learning process (Mardikanto, 2009). Assistance to farmers through farmer groups is intended to foster and develop the participation of farmers in the independence of farmers. Farmer group assistance is a series of activities that aim to enable and empower members of farmer groups so that they have the same goal in enhancing their knowledge and skills. The formation of farmer groups is based on the similarity of interests among group members to have the ability to access all resources, both resources in the form of natural resources, people, capital, information, and infrastructure in developing farming (Jamal, 2007).

The objectives of farmers in managing farming businesses are among others to: (1) fulfill their food needs throughout the year; (2) fulfill their basic needs; (3) to meet the educational needs of their 
children; (4) to save as a life insurance; and (5) so that it can be accepted by the community and gain selfesteem and reputation (FAO, 1990). This study aims to describe the efforts made by field agricultural extension officers in empowering farmers to improve the performance of farming in the "Mugi Rahayu" Farmer Group in Tegalsari Village, Jetis District, Ponorogo Regency, Indonesia.

\section{THEORETICAL FRAMEWORK}

\section{Empowerment of Farmer Communities}

Community empowerment is a concept of economic development that summarizes social values. Empowerment is a pattern of development that is people-centered and aimed at building community independence (Zubaedi, 2013). Community empowerment is also an effort to meet the needs of individuals, groups and the wider community so that they have the ability to make choices and control their environment in order to fulfill their desires including their accessibility to resources related to their work, social activities, and other things (Tharesia, 2014)

Community empowerment aims to improve the quality of life and welfare of every individual and community in: (1) economic improvement, namely food sufficiency; (2) social improvement in terms of education and health; (3) independence from all forms of oppression; and (4) guaranteed security (Mardikanto $\&$ Soebianto, 2012). In the field of agriculture the purpose of empowerment is directed to the realization of improved institutional institutions (better organizing) namely the establishment of cooperation and partnerships with stakeholders, improvement of community life (better community), improvement of business and the environment (better environment) for the survival of farming (Tharesia, 2014).

Community empowerment will not work without the active participation of the community which in this case is the farming community. Farmers become the main actors in solving problems faced. Petan community empowerment can be done through farmer groups that have been formed in each village. Farmer groups are a group of farmers consisting of adult farmers, both men and women, and cadets, namely young people or young women who are related informally in a group area on the basis of harmony and shared needs, common interests, similarity in environmental conditions (social, economic, resources) and familiarity to improve and develop the members' business as stated in the Guidance for the Development of Farmer Groups and the Joint Farmers Group Regulation of the Minister of Agriculture (Permentan) No. 82 tahun 2013. The formation of a Farmer Group (Poktan) has the aim to solve problems faced by farmers that cannot be solved by the farmers themselves individually (Nuryanti \& Swastika, 2011). Farmer groups can be a means of communication between farmers in finding alternative solutions in solving problems so that the productivity and welfare of farmers increases.

Farmer groups are non-formal institutions in rural areas as a place for farmers to develop knowledge, skills, and attitudes to improve their ability to manage farming so that they become independent farmers. Poktan also has a role as a learning class for fellow farmers. All organized education (learning) activities held outside the formal system, either alone or as part of broad activities intended to provide services to certain students in achieving learning goals are called non-formal education (Coombs in Joesoef, 1992).

\section{Agricultural Extension as Non-Formal Education}

Agricultural extension is an important factor to determine the success of farming performance. Agriculture extension to farmers is a process that has a different way of working with other education programs, namely: (1) helping farmers analyze the situation being faced and making estimates in the future; (2) helping farmers to realize the possibility of problems from analysis what has been done; (3) increase knowledge and develop insight into the problem and help structure the framework based on the knowledge possessed by farmers; (4) help farmers obtain specific knowledge related to how to solve problems they are facing; (5) help farmers to decide the right choice in their opinion; (6) increasing the motivation of farmers to be able to apply their choices; and (7) helping farmers to evaluate and improve decision-making skills (Ban \& Hawkins, 1999). The agricultural extension process can run well if it is supported by professional extension workers both institutionally and extension methods used. Agricultural extension workers have a role as facilitators, motivators and supporters in improving the performance of farmers' businesses.

The extension activities not only focus on technology transfer but include the entire learning process for the main actors so that they are willing and able to help and organize themselves in accessing market information, technology and other resources as an effort to improve business efficiency and welfare in the preservation of environmental functions (Wardani $\&$ Waridin, 2005) Agricultural extension workers have a duty to eliminate barriers faced by farmers by providing information and providing views on the problems faced by farmers. Correct information about the management of natural resources that are good and right in accordance with the conditions of the land owned by Sagat is beneficial for farmers to improve the production of farming without damaging the environment.

Agricultural extension is non-formal education for farmers which includes activities in increasing knowledge and skills of extension workers to farmers and their family members that take place through the teaching and learning process (Mardikanto, 2009). The agricultural extension process carried out by extension workers is a mediator between the founding institutions and the farmers (Sastraatmaja, 1993). Field agricultural extension officers are located institutionally at the Agricultural Extension Center (BPP) which has the main task of carrying out agriculture extension in the fields of agriculture, fisheries and forestry. Based on the results of research conducted by Astuti (2015) field agricultural extension 
workers have the role of: (1) as mentors providing nonformal education such as providing agriculture extension in accordance with the latest information from relevant agencies and providing direction on planning during planting and helping farmers in making decisions regarding solving problems faced by farmers; and (2) as an evaluation and monitoring of farmers' activities.

\section{METHODS}

This study attempts to express in depth and examine the characteristics in existence, phenomena and factors that influence the implementation of farmer empowerment. To be able to uncover these problems in this study, qualitative research-oriented approach is used to illustrate the efforts made by field agricultural extension officers in empowering farmers to improve the performance of farming in the "Mugi Rahayu" Farmer Group in Tegalsari Village, Jetis District, Ponorogo Regency.

This research is a research that uses a qualitative approach with a qualitative approach with phenomenological design. Miles and Hubberman (2009) qualitative research is research that deals with complicated things, in-depth interviews, has broad, concrete, and direct meaning. To get all the phenomena and actual in this study, researchers are instruments that are directly in the field and collect phenomena contained in the situation and dynamics of field agricultural extension officers in their activities to assist farmers in improving farm performance for farmers who are members of farmer groups.

The observation technique used in this study is participatory observation to obtain data about the subject's behavior and the interaction with other components. This is related to Merriam's statement (1998) qualitative research is that it ussually involves fieldwork. The research must be physically go to the people, settings, site, institution (the field) in order to observe behavior in its natural settings. Observation is the right technique in this study. To get direct information from research subjects such as reasons, perceptions, hopes and goals, these observations were followed up by direct interviews. Interview is a data collection technique with a conversation that aims to obtain information about events, activities, organizations, feelings, motivation, recognition, and seriousness (Sutopo, 1996).

The use of interview techniques is primarily to explore and obtain data that cannot or are difficult to trace with observation techniques. Researchers used semi-structured interview techniques where the researcher had interview guidelines that contained the main issues to be asked but still provided an opportunity for the interviewee to express his ideas, feelings, and ideas. This study also uses documentation techniques, namely taking photos. This technique is used to obtain data that is not netted through observation and interviews. The documentation in question is like data about the status of the person, the physical condition of the extension site, facilities and infrastructure, and events related to the research context.

\section{RESULTS AND DISCUSSION} Implementation of Agriculture Extension in the "Mugi Rahayu" Farmer Group in Farmer Empowerment

The research data states that the farmer group "Mugi Rahayu" is a place for farmers to exchange information about all things related to agriculture and cultivation of crops that are farming. This is consistent with the statement of Nuryanti \& Swastika (2011) that farmer groups have a goal to solve problems faced by farmers who cannot be faced alone. Extension activities are routinely carried out in the farmer group "Mugi Rahayu" especially when there are simultaneous planting programs or introduction to prevention and control of plant diseases.

Agriculture extension is organized by farmer groups together with field agricultural extension workers. The management of the farmer group will formulate a plan for the implementation of agriculture extension together with field agricultural extension officers in agreeing on extension material and resource persons who will be brought in when needed during the activity. Farmer groups will hold discussions with members of the farmer group and agree on the time and place of activities that are adjusted to the time available to each member of the farmer group. This is consistent with the statement of Mardikanto (2009) that agricultural extension is a non-formal education for farmers which includes activities to increase knowledge and availability of extension workers to farmers and their families that take place through teaching and learning activities.

The implementation of extension activities is left entirely to the farmer groups, this is because the extension target which is a farmer is a member of the farmer group so that to gather the target learning is easier for the field agriculture instructor when through the farmer group. The farmer group provides learning programs needed by its members with the aim of solving the problems being faced so that they can find the right solution and prevent bigger problems from arising during the planting season. This is consistent with Ban \& Hawkins (1999) opinion that one component of the success of agricultural extension is the role of farmers themselves. Farmer groups have a role to foster awareness of farmers who are members of farmer groups to have the ability to recognize problems and find alternative solutions in accordance with their problems and potential.

Extension participants consisting of members of farmer groups who are adults have a different way of learning than the way children learn. They always agree in advance about the things that will be the discussion in extension activities and the time needed so as not to interfere with their daily activities in carrying out their main activities. Extension agents can influence targets through their roles as education, innovation, facilitation, consultation, supervision, monitoring, evaluation, and as a farmer advisor (Mardikanto, 2009). The role of the extension agent must be adjusted to the characteristics of the farmer and the potential of the existing area. This is consistent 
with the opinion expressed by Mardikanto (2009) that counseling is not an instruction, coercion or patronizing action, but is a participatory learning process to find the best, easiest, and cheapest alternative time and solutions.

The results of the study stated that the evaluation of learning was carried out based on observations by field agriculture instructors after the extension. Observations were made to see how far farmers were able to carry out the knowledge and skills that had been received while on the land they owned. This is in accordance with what Ban \& Hawkins (1999) stated that through counseling activities farmers are expected to be able to improve their lives, and make effective decisions in solving their problems.

\section{Meaning of Efforts to Improve Farmer Business Performance}

Farmers' empowerment cannot be done alone by field agricultural extension workers, but also the role of farmers and the organizations that protect them is the farmer group. The role of the three parties will support efforts to improve farm performance in accordance with the objectives expected by each party, namely the resolution of the problems faced by farmers in a good and appropriate way. Extension agents can influence farmers through their roles as education, innovation, facilitation, consultation, supervision, monitoring, evaluation, and as a farmer advisor (Mardikanto, 2009). Farmer empowerment must be adjusted to the characteristics of farmers and regional potential.

Farmer groups can institutionally develop by empowering a group of farmer group members who have the same goal, so that togetherness is needed between members and share the same views and interests. This is stated by Ministry of Agriculture (2007) that farmer groups have different characteristics from other institutions, farmer groups have the following characteristics: (1) to know each other, to be familiar with and trust each other among members; (2) to have the same views and interests in strive; (3) have similarities in tradition or settlement, type of business, economic status, and ecology; and (4) there is a division of duties and responsibilities of fellow members based on mutual agreement. These institutional characteristics make farmer groups able to enable their group members to become more empowered and able to solve problems independently by assisting from field agricultural extension workers.

Farmer empowerment carried out by extension agents and farmer groups is carried out in a participatory nuance so that the principles of equality, responsibility, accountability and cooperation between the parties involved. The group formed on the basis of the similarity of interests among farmers makes the farmer group have the ability to access all the resources they have in developing the farming they do (Jamal, 2007). The role of extension workers in empowering farmers is to make the target aware of the opportunities that exist to plan, provide the ability of the community to determine the program, provide the ability to control their own future, and provide the ability to master the social environment (Novita, 2013).

Improving the performance of farms can not only be seen from the increase in the number of farmers' income each year but also must be seen from the empowerment of farmers both in the addition of knowledge, skills, and attitudes of farmers in recognizing the possible problems that arise and independently farmers are able to get a problem in accordance with the characteristics and the condition of the land he owns.

\section{CONCLUSION}

The implementation of farmer empowerment in the farmer group "Mugi Rahayu" is carried out through extension activities carried out by field agricultural extension workers. Extension activities are carried out routinely to deliver material that is felt to be the learning needs of farmers in recognizing problems and finding solutions to existing problems in accordance with the characteristics and potential of the land owned.

Empowering farmers through extension activities carried out through a series of processes consisting of planning, implementing and evaluating. The series of processes are carried out jointly between farmer groups, extension agents, and farmers as learning targets. Improving the performance of farms is not only seen from the addition of the amount of farm income for each harvest period, the empowerment of farmers can also be seen from the ability of farmers to recognize problems and seek problem solving independently.

\section{REFERENCES}

[1] Astuti, I. W. 2015. Peran Penyuluh Pertanian Lapangan dalam Peningkatan Produktivitas Pertanian di Desa Batu Timbau Kecamatan Batu Ampar Kabupaten Kutai Timur. eJornal Ilmu Pemerintahan, 3(1), 433-442.

[2] Ban, V. A. W., \& Hawkins, H. S. 1999. Penyuluhan Pertanian. Yogyakarta: Kanisius.

[3] Mardikanto, T. 2009. Sistem Penyuluhan Pertanian. Surakarta: Universitas Sebelas Maret.

[4] Mardikanto, T., \& Soebianto, P. 2012. Pemberdayaan Masyarakat dalam Perspektif Kebijakan Publik. Bandung: Alfabeta.

[5] Merriam, S. B. 1998. Qualitative Research and Case Study Applications in Education. San Fransisco: Jossey-Bass Publishers.

[6] Milles, M. B., \& Hubberman, A. M. 2009. Analisis Data Kualitatif. Jakarta: Penerbit Universitas Indonesia.

[7] Sastraatmadja, E. 1993. Penyuluhan Pertanian. Bandung: Penerbit Alumni.

[8] Sutopo, H. B. 1996. Metodologi Penelitian Kualitatif. Surakarta: Universitas Sebelas Maret.

[9] Tharesia, A. 2014. Pemberdayaan Berbasis Masyarakat. Bandung: Alfabeta.

[10] Zubaedi. 2013. Pengembangan Masyarakat. Jakarta: Kencana. 